\author{
Dorota Murzyn \\ Uniwersytet Pedagogiczny \\ im. Komisji Edukacji Narodowej \\ w Krakowie
}

\title{
Przedsiębiorczość w regionie a środki pomocowe Unii Europejskiej
}

Przedsiębiorczość postrzegana jest, obok pracy, kapitału i ziemi, jako jeden z głównych czynników produkcji. Można ją zdefiniować jako „trwałą kompetencję, przejawiającą się dynamicznym reagowaniem na zjawiska pojawiające się w otoczeniu i przynoszącą efekty w postaci przejścia na wyższy poziom rozwoju” (Strojny 2006). Przedsiębiorczość może być rozumiana jako proces (działania w kierunku tworzenia i budowania nowego przedsiębiorstwa), zespół cech (przedsiębiorczy to taki, który wyróżnia się aktywnością, dynamizmem, umiejętnością dostrzegania szans i ich wykorzystywania, skłonnością do podejmowania ryzyka) lub innowacyjność (nowatorstwo, ulepszenie, wprowadzanie nowości) (Makieła 2008). W kategoriach społecznych przedsiębiorczość postrzegana jest jako ludzka aktywność, natomiast w kategoriach ekonomicznych związana jest z powstawaniem i rozwojem przedsiębiorstw. Jednym z uwarunkowań rozwoju przedsiębiorczości, obok polityki rządu, regulacji prawnych i podatkowych aspektów działalności gospodarczej, jest dostępność kapitału. Większe możliwości pozyskania kapitału na inwestycje, które oferują m.in. fundusze strukturalne Unii Europejskiej, pozwalają przedsiębiorstwom skuteczniej konkurować na rynkach krajowych i międzynarodowych. Środki te odgrywają także istotną rolę w pobudzaniu przedsiębiorczości w danym regionie w celu pozyskiwania dofinansowania i wykorzystywania zasobów endogenicznych.

Przedsiębiorczość w regionie można badać na różne sposoby i w odniesieniu do różnych podmiotów. Najczęściej termin ten stosowany jest w odniesieniu do przedsiębiorstw, ich powstawania i rozwoju. Prowadzone są badania na temat rozwoju przedsiębiorczości regionalnej oraz roli MŚP w tym procesie. Inny nurt badań skupia się na analizie czynników rozwoju przedsiębiorczości regionalnej. Ważną rolę odgrywa tutaj administracja publiczna, która może prowadzić działania mające na celu wspieranie i promowanie przedsiębiorczości. Te ujęcia nie wyczerpują jednak analizy zjawiska przedsiębiorczości w układach regionalnych. Artykuł skupia się na tych aspektach, które mają związek z funduszami pomocowymi Unii Europejskiej.

\section{Rola przedsiębiorstw w rozwoju przedsiębiorczości a środki pomocowe UE}

Gospodarka rynkowa stwarza korzystne warunki do rozwoju przedsiębiorczości. Doświadczenia różnych krajów wskazują przy tym, że aktywność gospodarczą najbardziej motywuje własność prywatna i to ona jest warunkiem inicjatyw przedsiębiorczych. Około 99,8\% firm działających na obszarze Unii Europejskiej stanowią małe i średnie przedsiębiorstwa, które potrafią skutecznie wykorzystywać nisze rynkowe i przystosowywać się do zmieniających się warunków. W Polsce także udział tego sektora jest znaczny i bliski średniej dla wszystkich krajów UE. Podobnie jest w przypadku wskaźnika liczby firm sektora MŚP przypadających 
na 1 tys. mieszkańców. W Polsce kształtuje się on na poziomie 37 (wobec 40 dla UE-27) (dane za 2007 rok, Eurostat 2008), co plasuje nas w środku stawki państw UE.

Rozwój przedsiębiorczości w regionach obrazują w pewnym stopniu zmiany liczby przedsiębiorstw, w szczególności liczba powstających nowych firm. Rozwój tak rozumianej przedsiębiorczości wspierany jest także przez fundusze strukturalne Unii Europejskiej. Wsparcie tych, którzy mają dobre pomysły i są chętni do podjęcia ryzyka rozpoczęcia działalności gospodarczej na własny rachunek, jest szczególnie istotne ze względu na ogromną rolę sektora małych i średnich przedsiębiorstw w rozwoju gospodarczym regionu. Kompleksowym podejściem w zakresie rozwoju i wspierania przedsiębiorczości w pierwszym okresie członkostwa (2004-2006) było m.in. Działanie 2.5 Zintegrowanego Programu Operacyjnego Rozwoju Regionalnego - Promocja przedsiębiorczości. Jego celem było aktywne wspieranie zatrudnienia poprzez stymulowanie powstawania nowych mikroprzedsiębiorstw. Zaprojektowane było ono jako kompleksowe wsparcie szkoleniowo-doradcze i finansowe dla osób, które chciały rozpocząć działalność gospodarczą na własny rachunek. Do końca 2008 r. ze wsparcia w ramach tego działania skorzystało ponad 6,5 tys. osób, w efekcie czego stworzono 8572 małych firm ${ }^{1}$. W latach 2007-2013 podobne wsparcie świadczone jest przede wszystkim przez Program Kapitał Ludzki - Działalnie 6.2 Wsparcie oraz promocja przedsiębiorczości i samozatrudnienia. Poza wsparciem dla osób zamierzających rozpocząć działalność gospodarczą w ramach tego działania realizowane są projekty dotyczące promocji przedsiębiorczości i samozatrudnienia oraz projekty zmierzające do upowszechniania dobrych praktyk z zakresu rozwoju przedsiębiorczości. Do końca 2008 roku 19893 osoby otrzymały środki na podjęcie działalności gospodarczej (Ministerstwo Rozwoju Regionalnego 2009b). Liczby te będą jeszcze większe, jeśli dodamy do nich te firmy, które zostały utworzone dzięki wsparciu innych programów (np. Działanie 1.2 Sektorowego Programu Operacyjnego Rozwój Zasobów Ludzkich - Perspektywy dla młodzieży, wsparcie osób odchodzących z rolnictwa), szczególnie promujących transfer wiedzy i rozwój działalności gospodarczej typu spin off lub spin out.

Ryc. 1. Zmiany liczby zarejestrowanych firm w latach 1999-2003 i 2004-2007

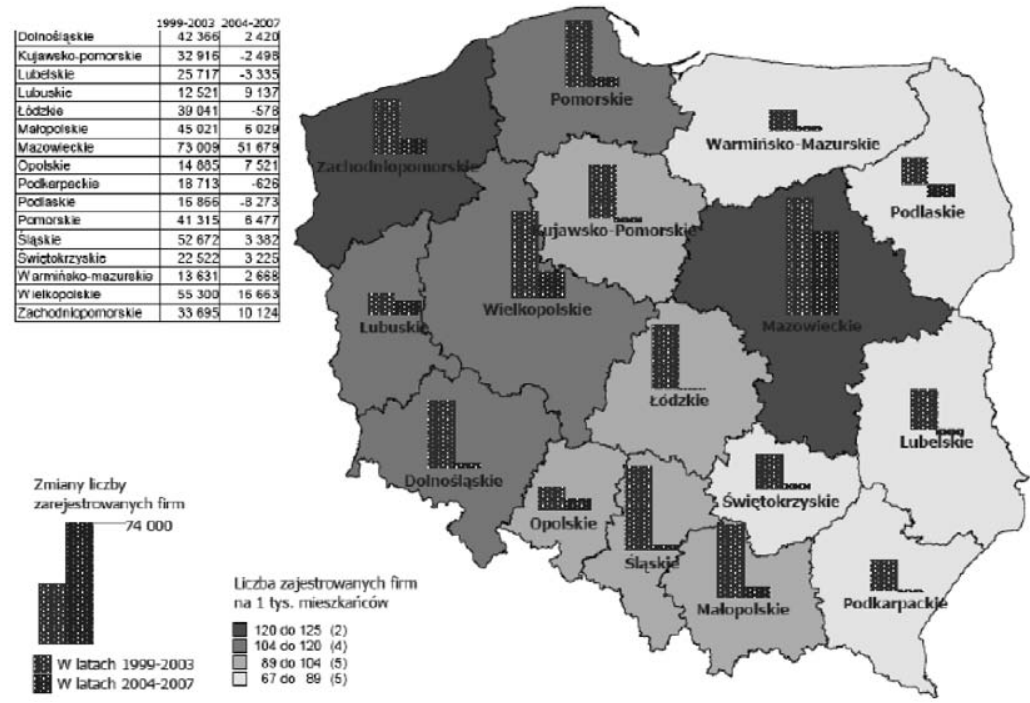

Źródło: Ministerstwo Rozwoju Regionalnego na podstawie danych GUS, za: Ministerstwo Rozwoju Regionalnego 2009a, s. 74.

\footnotetext{
${ }^{1}$ Dane MRR, Roczne raporty z wdrażania ZPORR, www.zporr.gov.pl
} 
Jeśli przyjrzymy się jednak zmianom liczby zarejestrowanych firm w regionach Polski w okresie przed przystąpieniem do Wspólnoty i w pierwszych latach po akcesji (ryc.1), to możemy zauważyć, że pierwsze lata członkostwa w UE, kiedy dostępne już były środki z funduszy strukturalnych, cechują się bardzo niską dynamiką w tym zakresie. Lata przed akcesją Polski do UE (1999-2003) cechowały się dynamicznym wzrostem liczby firm - o ponad 17\%, przy czym wzrost ten nastapił we wszystkich województwach. Z kolei w latach bezpośrednio po akcesji (2004-2007) dynamika ta znacznie spadła i nastąpił wzrost liczby podmiotów zaledwie o 3\%, a w przekroju międzyregionalnym aż w pięciu województwach nastąpił spadek liczby firm (podlaskie, lubelskie, kujawsko-pomorskie, podkarpackie i łódzkie). Można wyciągnąć wniosek, że albo regiony w różnym stopniu wykorzystują środki UE na rozwój przedsiębiorczości, albo pomoc ta jest nieefektywna (ze wszystkich firm utworzonych w ramach ZPORR, po 18 miesiącach od ich utworzenia, na rynku nadal funkcjonowało zaledwie $68 \% \mathrm{z}$ nich).

Ryc. 2. Liczba i rodzaj projektów realizowanych przez przedsiębiorstwa i współfinansowanych ze środków UE w przekroju regionalnym
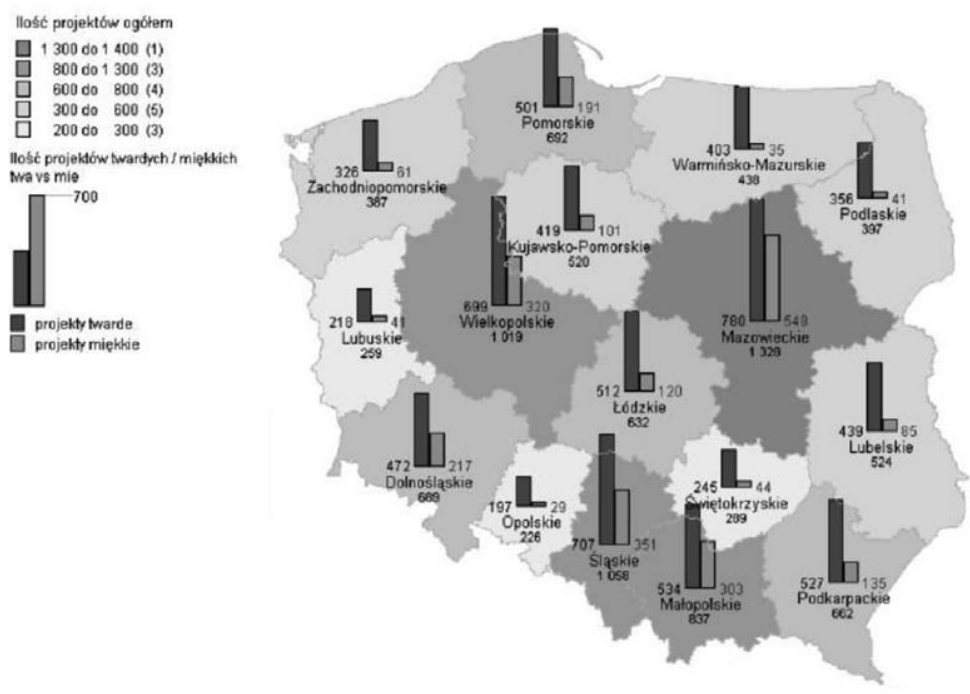

Źródło: Ministerstwo Rozwoju Regionalnego 2008b, s. 9.

Rozwój przedsiębiorczości w regionach obrazuje nie tylko sytuacja w zakresie tworzenia nowych firm, ale i rozwój już istniejących. Jaką rolę w tym procesie odgrywają środki pomocowe Unii Europejskiej? Przedsiębiorstwa są jednym z głównych beneficjentów funduszy strukturalnych UE. Środki te mogą przy tym być przeznaczone na różne rodzaje przedsięwzięć, m.in.: podnoszenie konkurencyjności przedsiębiorstw, poszukiwanie i wdrażanie nowych rozwiązań technologicznych, inicjowanie działalności innowacyjnej, promocja eksportu, szkolenia zawodowe dla pracowników i kadry zarządzającej. Od początku uruchomienia tego typu pomocy polscy przedsiębiorcy aktywnie pozyskują dofinansowanie. Porównując liczbę złożonych wniosków do alokacji dostępnej w ramach poszczególnych programów i działań, wyraźnie można zaobserwować, że programy przeznaczone dla przedsiębiorstw budziły największe zainteresowanie. W latach 2004-2007 liczba projektów współfinansowanych przez fundusze strukturalne Unii Europejskiej związanych ze wsparciem przedsiębiorstw sięgnęła 15667 (18,5\% wszystkich projektów), a ich wartość przekroczyła 15 mld zł (16\% wartości 
projektów ogółem) (Ministerstwo Rozwoju Regionalnego 2008a). Przyglądając się mapie Polski i liczbie projektów w województwach, widać jednak wyraźne różnice regionalne w tym zakresie (ryc. 2).

Najwięcej projektów realizowały przedsiębiorstwa w województwach silnych ekonomicznie (mazowieckie, śląskie, wielkopolskie), najmniej natomiast w województwach: opolskim, lubuskim i świętokrzyskim, co przede wszystkim było konsekwencją wielkości regionalnej gospodarki. Interesujący wniosek można wyciagnąć, porównując liczbę projektów twardych i miękkich w poszczególnych regionach. Zdecydowana przewaga projektów twardych wystąpiła w województwach Polski Wschodniej, co może oznaczać większe potrzeby w zakresie inwestycji infrastrukturalnych w tych województwach.

W latach 2004-2006 przedsiębiorstwa korzystały przede wszystkim ze wsparcia w ramach Sektorowego Programu Operacyjnego Wzrost Konkurencyjności Przedsiębiorstw, ale także w ramach Zintegrowanego Programu Operacyjnego Rozwoju Regionalnego (Działanie 3.4 Mikroprzedsiębiorstwa), Sektorowego Programu Operacyjnego Rozwój Zasobów Ludzkich, Sektorowego Programu Operacyjnego Rybołówstwo i Przetwórstwo Ryb oraz Sektorowego Programu Operacyjnego Restrukturyzacja i Modernizacja Sektora Żywnościowego oraz Rozwój Obszarów Wiejskich. Wśród wszystkich realizowanych projektów przeważały tzw. projekty twarde, czyli inwestycyjne. Poprawa konkurencyjności przedsiębiorstw nastąpiła także poprzez wzrost jakości usług świadczonych przez instytucje otoczenia biznesu (WYG International, PSDB 2007). Dzięki funduszom unijnym bardziej dostępne stało się zewnętrzne finansowanie. W obecnym okresie programowania 2007-2013 przedsiębiorstwa mogą uzyskać środki na rozwój głównie dzięki Programowi Innowacyjna Gospodarka, a pulę tę powiększają regionalne programy operacyjne.

Rozwój przedsiębiorstw i ich efektywne funkcjonowanie jest podstawą wzrostu gospodarczego. Jednym ze środków prowadzących do osiagnięcia tego celu są innowacje. Innowacyjność gospodarki jest istotnym warunkiem wzrostu konkurencyjności przedsiębiorstw. Na sukces innowacyjny wpływa wiele różnorodnych czynników. Wysoki poziom innowacyjności gospodarki spowodowany jest głównie przez działanie mechanizmu konkurencyjnego wśród przedsiębiorstw. Ważnym elementem tego sukcesu jest też interwencjonizm państwowy w postaci odpowiedniej polityki innowacyjnej, wyrażającej się min. poprzez nakłady na badania i rozwój. Innowacyjność małych i średnich przedsiębiorstw wspierają także fundusze UE.

Wyniki badań przeprowadzonych w Instytucie Nauk Ekonomicznych PAN (Kotowicz-Jawor 2008) wskazują, że fundusze strukturalne są ważnym stymulatorem jakościowych, proinnowacyjnych przemian funkcjonowania sfery rozwojowej przedsiębiorstw. Wywierają one szczególnie korzystny wpływ na zwiększenie konkurencyjności (23\% badanych firm realizujących projekty z udziałem dofinansowania wspólnotowego wskazało na taki efekt) oraz rozwój przedsiębiorstw: wzrost nakładów inwestycyjnych (22\% firm), zwiększenie zatrudnienia $(16 \%)$ oraz innowacyjność (15\%). Jednym z istotnych efektów realizacji projektów współfinansowanych z funduszy strukturalnych UE jest ich zdolność do generowania dodatkowych inwestycji związanych z interwencjami unijnymi w sposób bezpośredni lub pośredni. Zgodnie z wynikami badania ewaluacyjnego, którego celem była ocena wpływu funduszy strukturalnych na wzrost konkurencyjności mikroprzedsiębiorstw (Pracownia Badań i Doradztwa „Re-Source” 2007), efekt dźwigni oraz efekt mnożnikowy funduszy unijnych w przypadku tych przedsiębiorstw jest znaczący. Ponad 82\% badanych mikroprzedsiębiorców objętych wsparciem zadeklarowało, że uruchomili dodatkowe środki własne na realizację projektów przewyższające kwotę wymaganego wkładu własnego (efekt dźwigni). Projekty realizowane 
przez mikroprzedsiębiorstwa w ramach polityki spójności generują również dodatkowe działania inwestycyjne nieobjęte wsparciem w ramach danego projektu (efekt mnożnikowy). Ponad $61 \%$ badanych mikroprzedsiębiorców zadeklarowało, iż w wyniku wsparcia zainicjowali kolejne działania inwestycyjne.

Głównym wyznacznikiem konkurencyjności i jej podstawową cechą jest zatem innowacyjność, natomiast zasadniczym nośnikiem innowacyjności są przedsiębiorstwa. Są one także najważniejszymi podmiotami realnych procesów gospodarczych w regionie. Konkurencyjność regionów może być zatem postrzegana przez pryzmat przedsiębiorstw zlokalizowanych w regionie. Wyniki działalności przedsiębiorstw decydują o pozycji rynkowej ich samych, ale też wpływają na kierunki i tempo rozwoju regionu, w którym są zlokalizowane.

\section{Rola samorządów w rozwoju przedsiębiorczości a środki pomocowe UE}

Rozwój przedsiębiorczości w regionie uzależniony jest od wielu różnych czynników. Wśród nich są czynniki ekonomiczne (np. kapitał, inwestycje, infrastruktura ekonomiczna, przejrzysty system podatkowy), społeczne (np. aktywność ludności, kwalifikacje miejscowej kadry) i techniczne (w tym: dostępność komunikacyjna, dostęp do nowoczesnych technologii, poziom rozwoju infrastruktury). Obok nich ważną rolę odgrywają czynniki polityczne, takie jak stabilna sytuacja polityczna czy przychylność władz samorządowych. Zakres obecności i aktywności państwa w różnych dziedzinach (a szczególnie w gospodarce) od lat jest przedmiotem sporów i dyskusji między naukowcami, politykami i obywatelami. Jednak bez względu na to, po której stronie tego dyskursu się znajdujemy, trudno się nie zgodzić, że współczesne państwo poprzez swoje organy może efektywnie oddziaływać na otoczenie. Funkcjonowanie gospodarki i jej efektywność zależy m.in. od kompetencji i uprawnień władz regionalnych i lokalnych. Polityka intraregionalna oddziałuje istotnie na czynniki rozwoju i konkurencyjności regionu. Czynniki rozwoju można też traktować jako bariery, jeśli kształtują się niekorzystnie dla danego obszaru. Stąd niezwykle istotne jest ich właściwe zidentyfikowanie, aby możliwe było pokonanie barier i wykorzystanie potencjału, jakim obdarzony jest dany region.

Głównym wyznacznikiem skutecznej aktywności w dziedzinie gospodarki organów administracji samorządowej jest przedsiębiorczość. Stanowi ona zasadniczą siłę napędową i podstawę relacji między administracją publiczną a gospodarką regionalną. W odniesieniu do administracji publicznej rozważa się przy tym głównie kwestie działań mających na celu wspieranie i promowanie przedsiębiorczości, rozumianej jako podejmowanie i rozszerzanie działalności gospodarczej przez podmioty gospodarcze na terenie danej jednostki samorządu terytorialnego. Wśród instrumentów wspierania przedsiębiorczości stosowanych przez władze regionalne do najważniejszych należą: tworzenie i rozwój infrastruktury ułatwiającej podejmowanie i prowadzenie działalności gospodarczej, działania promocyjno-organizacyjne, tworzenie korzystnych warunków finansowych do podejmowania działalności gospodarczej. Instrumenty wspierania przedsiębiorczości można podzielić na (Makieła 2008): dochodowe i wydatkowe. Do pierwszej grupy zalicza się politykę fiskalną samorządów, jej stałość i przejrzystość oraz stosowane ulgi i zwolnienia. Najważniejszymi instrumentami wydatkowymi są $\mathrm{z}$ kolei inwestycje regionalne, $\mathrm{w}$ tym inwestycje infrastrukturalne.

Władze regionalne, tworząc lepsze warunki dla rozwoju przedsiębiorczości, mogą wpływać istotnie na jej kształtowanie się na danym obszarze. Czynniki lokalizacji bezpośrednich inwestycji zagranicznych w Polsce świadczą jednak, iż wpływ władz regionalnych i lokalnych na kierunki napływu kapitału jest znacznie ograniczony (ryc. 3). W zasadzie tylko stan infrastruktury technicznej jest czynnikiem mającym istotne znaczenie dla inwestorów i leżącym w gestii władz samorządowych. Zakładając, że czynniki lokalizacji inwestycji są w dużym 
stopniu analogiczne do czynników rozwoju przedsiębiorczości w ogóle, wydaje się, że przedsiębiorcy oczekują od władz regionalnych przede wszystkim stworzenia odpowiedniej infrastruktury dla działalności gospodarczej.

Ryc. 3. Wpływ władz samorządowych na czynniki lokalizacji inwestycji

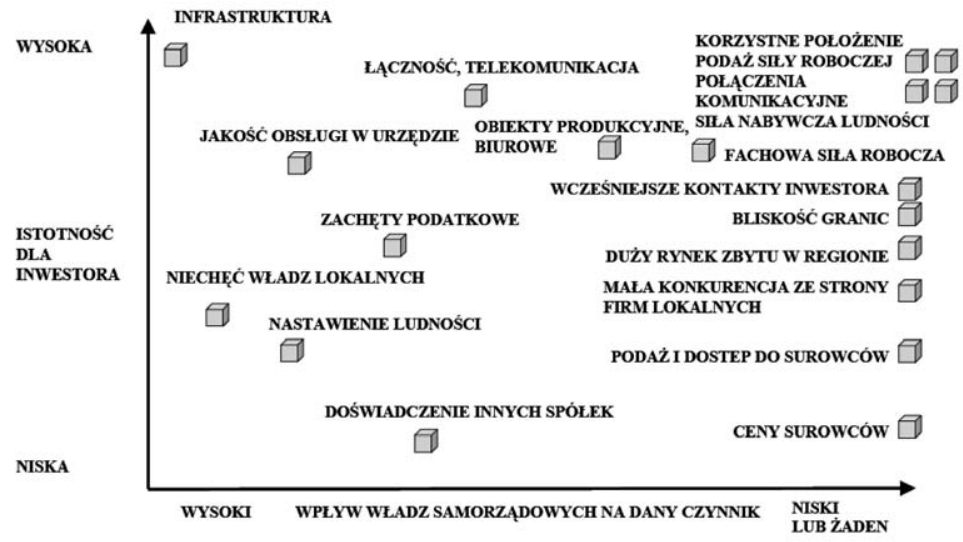

Źródło: Dziemianowicz, s. 12.

Władze regionalne wydają się zdawać z tego sprawę, przeznaczając coraz większe środki na rozwój infrastruktury na swoim terenie. Jednostki samorządu terytorialnego są największym beneficjentem funduszy UE. Środki te oferują większe możliwości pozyskania kapitału na inwestycje infrastrukturalne w regionach, stwarzają szansę dokonania modernizacji i rozbudowy systemu infrastrukturalnego. Analiza struktury dofinansowania UE w przekroju obszarów interwencji wskazuje na zdecydowaną przewagę projektów infrastrukturalnych w większości regionów Polski (ryc. 4).

Ryc. 4. Realizacja projektów współfinansowanych przez UE w regionach według obszarów wsparcia
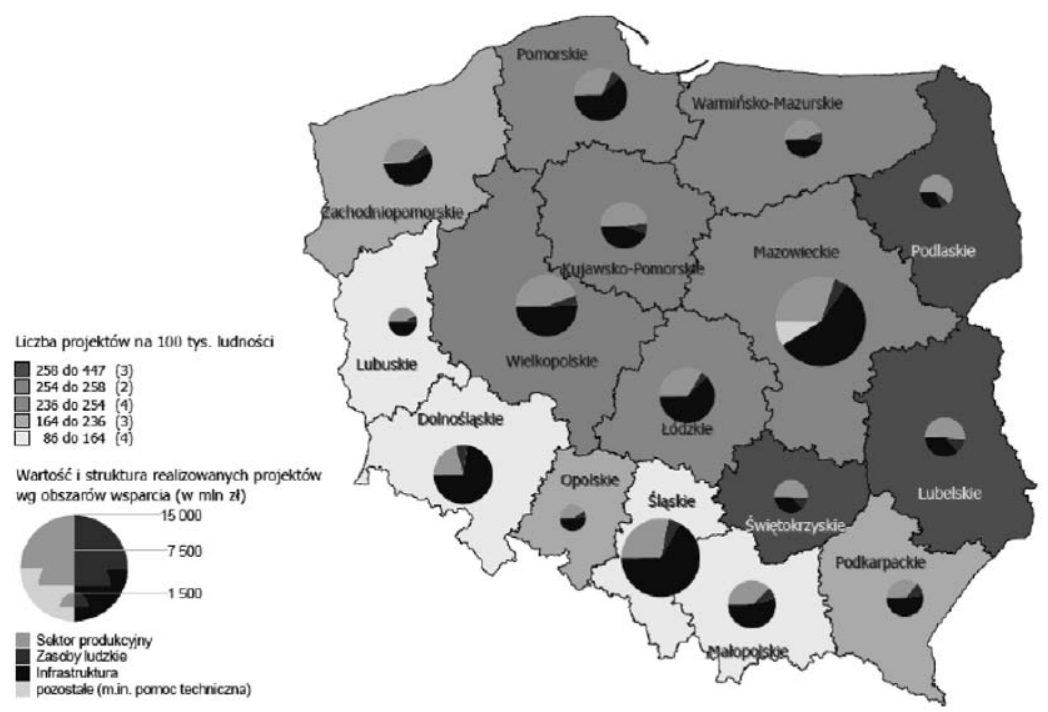

Źródło: Ministerstwo Rozwoju Regionalnego 2008a, s. 128. 
Wśród projektów realizowanych przez jednostki samorządu terytorialnego projekty z zakresu infrastruktury stanowiły ponad $80 \%$, co wskazuje na wyraźną koncentrację samorządów na tym obszarze. Duże projekty infrastrukturalne realizowane były przy tym przede wszystkim w silnych gospodarczo regionach. Fundusze strukturalne UE i Fundusz Spójności przyczyniły się do zmniejszenia roli infrastruktury jako bariery rozwojowej w regionach. Dzięki środkom UE stopniowo następuje poprawa jakości infrastruktury, ale jest ona nadal niewystarczająca w stosunku do poziomu rozwoju infrastruktury w większości krajów UE.

Spodziewać się można wzrostu roli czynników wynikających z aktywności władz lokalnych w celu przyciagnięcia kapitału. Lokalizacja inwestycji w regionach peryferyjnych w dużej mierze determinowana jest bowiem sprawnością administracyjną władz samorządowych. W celu wykorzystania potencjału rozwojowego i sprostania wyzwaniom globalnym władze regionalne muszą umiejętnie korzystać z instrumentów polityk publicznych, w tym instrumentów polityki regionalnej. Tylko wówczas będą w stanie stworzyć warunki dla właściwego wykorzystania zasobów wewnętrznych regionu oraz przyciągnięcia zasobów zewnętrznych i właściwego ich ukierunkowania.

Przyjmuje się, że przy wdrażaniu określonych strategii, administracja publiczna powinna się koncentrować na metodach niewładczych o charakterze kreatywnym (Potoczek 2001). Oznacza to odejście od klasycznego rozumienia administracji (modelu biurokratycznego Webera) zajmującej się przede wszystkim wprowadzaniem w życie reguł prawa w kierunku administracji będącej aktywnym uczestnikiem procesów społeczno-gospodarczych. Podstawową funkcję pełni tzw. zarządzanie strategiczne. Rozumie się przez nie ukierunkowany na przyszłość proces wyboru celów i kierunków rozwoju oraz metod i sposobów ich osiagania (Miszczuk, Żuk 2007). Zasadniczym elementem zarządzania strategicznego jest ustalenie długofalowych kierunków rozwoju, pozwalających na wykorzystanie istniejących szans i czynników rozwoju. Identyfikacja szans i możliwości oraz potencjalnych zagrożeń rozwoju jest warunkiem skutecznego zarządzania rozwojem regionalnym i lokalnym. Istotne jest przy tym także oddziaływanie władzy samorządowej na gospodarkę i społeczność tak, aby tworzyć warunki stymulujące wykorzystanie tych szans a ograniczenie zagrożeń rozwoju.

Podstawowym instrumentem zarządzania regionalnego i lokalnego jest strategia rozwoju, a planowanie strategiczne jest pierwszym i jednym z najważniejszych etapów zarządzania strategicznego. Strategia rozwoju stanowi zbiór celów i zamierzeń oraz kierunków działania, obrazujących koncepcję przyszłości danego układu terytorialnego. Jest ona instrumentem koordynującym politykę rozwoju regionalnego i lokalnego. Strategia rozwoju spełnia kilka ważnych funkcji. Po pierwsze, aktywizuje wspólne (w jej tworzenie powinni być zaangażowane podmioty sceny lokalnej i regionalnej) myślenie o przyszłości. Po drugie, w sytuacji wielości potrzeb i ograniczoności zasobów, pozwala koncentrować działania na najważniejszych celach, zapewniając większą efektywność. Wreszcie, jest ważnym instrumentem podnoszącym sprawność zarządzania publicznego. Może ona przy tym stanowić podstawę do ubiegania się o pozabudżetowe środki finansowe (np. środki pomocowe Unii Europejskiej). Innymi instrumentami zarządzania strategicznego w samorządzie terytorialnym są: studia i plany zagospodarowania przestrzennego, wieloletnie plany finansowe i wieloletnie plany inwestycyjne. Powinny być one przy tym skoordynowane ze strategią rozwoju realizowaną przez samorząd.

\section{Region jako podmiot przedsiębiorczości}

Systematycznie rośnie rola regionów w realizacji programów współfinansowanych z funduszy europejskich. W latach 2004-2006 największym programem współfinansowanym ze środków Unii Europejskiej był Zintegrowany Program Operacyjny Rozwoju Regionalnego (ZPORR), 
który absorbował prawie 40\% wszystkich funduszy strukturalnych przyznanych Polsce w tym okresie. Był to zarazem główny instrument wsparcia regionalnego. W obecnym okresie programowania (2007-2013) rolę taką spełniają przede wszystkim regionalne programy operacyjne. Udział tych programów w całości środków pochodzących z funduszy strukturalnych w latach 2007-2013 w Polsce przekroczył 36\%. To co prawda mniej niż we Włoszech czy Niemczech, ale więcej niż np. w Grecji. Środki te powiększają zdolności inwestycyjne samorządów, które są obecnie największym beneficjentem funduszy $U^{2}$. Wydatki na inwestycje dofinansowane przez UE w 2006 r. stanowiły ponad 30\% wszystkich inwestycji samorządów w Polsce. Intensywność wykorzystania środków unijnych jest jednak różna w różnych regionach Polski (ryc. 5).

Ryc. 5. Intensywność wykorzystania środków UE w regionach Polski (stan na koniec 2007 r.)

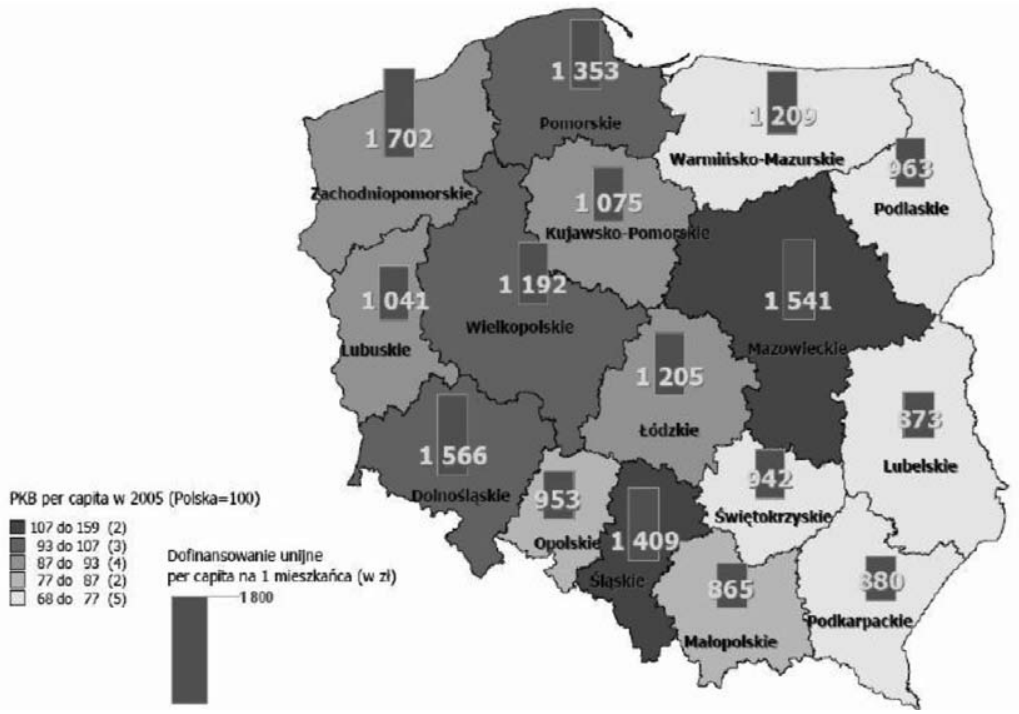

Źródło: Ministerstwo Rozwoju Regionalnego 2008a, s.126.

Województwa Polski Wschodniej mają zauważalnie mniejszy udział w wartości projektów i dofinansowaniu do nich w stosunku do zamieszkującego je odsetka ludności. Gdybyśmy wzięli jednak pod uwagę inny wskaźnik świadczący o aktywności regionów w zakresie wykorzystywania wsparcia unijnego - ilość projektów w przeliczeniu na 100 tys. mieszkańców, to sytuacja wygląda zupełnie inaczej. Wskaźnik ten jest z kolei znacznie wyższy w Polsce Wschodniej. Większa absorpcja środków w regionach silniejszych (zarówno w liczbach bezwzględnych, jak i w przeliczeniu na jednego mieszkańca) spowodowana jest m.in. tym, że województwa te realizowały duże projekty infrastrukturalne. Regiony Polski Wschodniej realizowały natomiast mniejsze projekty, stąd różnice w wartościach tych wskaźników.

Bez względu na to, jakim wskaźnikiem aktywności regionów będziemy się posługiwać, zdolność regionów do efektywnej absorpcji pomocy wydaje się być kluczową kwestią dla powodzenia w procesie rozwoju regionalnego. To raczej nie wielkość samej alokacji, a różnice w poziomie zdolności do skutecznego korzystania z funduszy strukturalnych wpływać będą na różnicowanie się polskiej przestrzeni. Fundusze Unii Europejskiej stanowią duże wyzwanie

\footnotetext{
${ }^{2}$ Biorąc pod uwagę fakt, że znaczna kwota przypada również podmiotom zaliczanym do sektora budżetowego, ok. 2/3 środków rozdysponowywana jest przez administrację publiczną.
} 
instytucjonalne i administracyjne. Badania potwierdzają tezę, że o zdolności absorpcyjnej funduszy unijnych decyduje przede wszystkim sprawność instytucjonalna samorządów terytorialnych. Mniej istotne są natomiast: poziom rozwoju czy też doświadczenia nabyte w fazie przedakcesyjnej. O zdolności absorpcyjnej decyduje też zdolność zgromadzenia środków własnych niezbędnych do absorpcji środków zewnętrznych oraz jakość zasobów ludzkich w regionach (zespołów zarządzających).

Rozwojowi gospodarczemu może sprzyjać jedynie sprawna administracja. Sprawność sprowadza się do dwóch zasadniczych elementów: skuteczności i gospodarności (Osiński 2003). Sprawność samorządów jest jednym z istotniejszych czynników rozwoju regionalnego. Nawet największe środki finansowe przeznaczone na wspieranie rozwoju nie przyniosą pożądanych rezultatów, jeśli będą zasilały niesprawne struktury. Sukces w zakresie efektywnej absorpcji środków strukturalnych zależy w dużej mierze od sposobu, w jaki funkcjonuje administracja poszczególnych jednostek samorządu terytorialnego. Badania w zakresie sprawności instytucjonalnej przeprowadził min. Instytut Badań nad Gospodarką Rynkową (ryc. 6).

Wyniki uzyskane przez IBnGR pozwalają lepiej ocenić poziom sprawności instytucjonalnej w zachodniej Polsce. Najlepsze wyniki uzyskała administracja województw: śląskiego, opolskiego, zachodniopomorskiego i lubuskiego, natomiast najsłabiej w tym zakresie wypadły województwa wschodniej Polski. Różne badania wskazują przy tym, że sprawność instytucjonalna administracji publicznej jest bardzo silnie skorelowana ze stopniem rozwoju społeczeństwa obywatelskiego w danym regionie (Swianiewicz z Herbstem, Lackowską i Mielczarkiem 2008).

O efektywnym wykorzystaniu środków pomocowych świadczy jednak nie sam fakt ich pozyskania czy poziom absorpcji, ale przede wszystkim jakość i sensowność spożytkowanych dotacji. Potrzebny jest przemyślany, skuteczny i efektywny system zarządzania rozwojem, dla którego środki UE są jedynie narzędziem, a nie celem samym w sobie.

Ryc. 6. Sprawność instytucjonalna w samorządach gminnych - wskaźnik syntetyczny

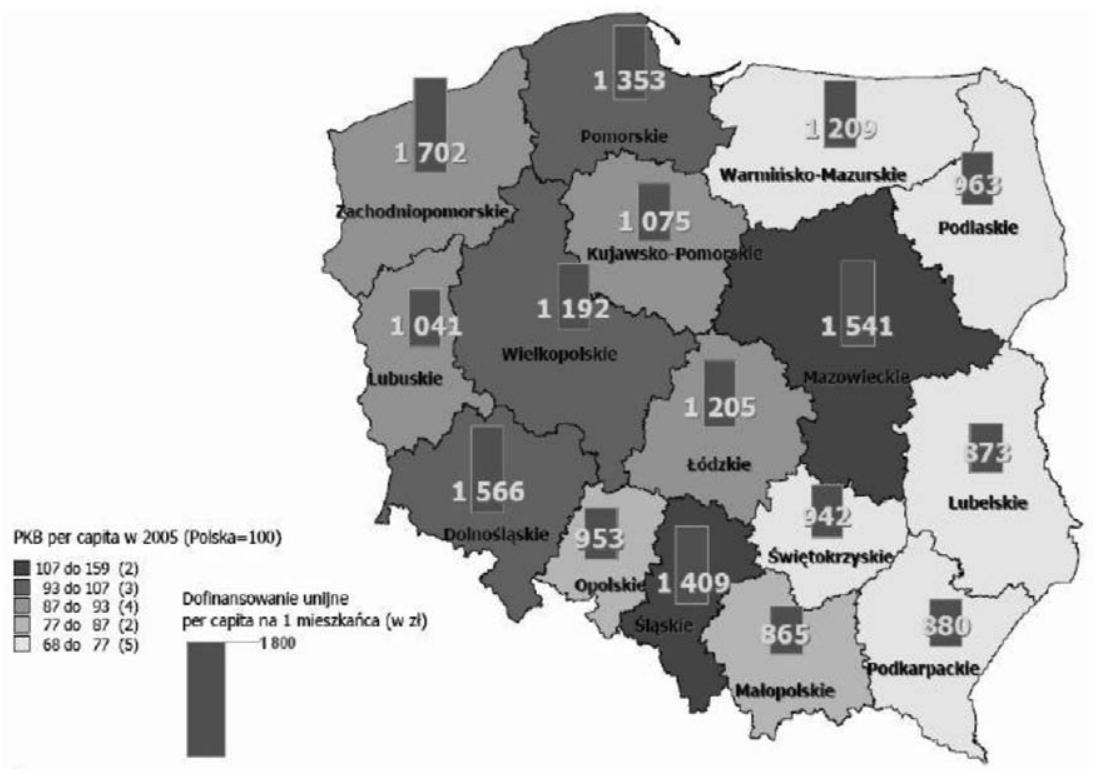

Źródło: Szomburg 2001, s.100. 
Regiony konkurują o środki finansowe z budżetu UE, nastąpił wzrost kreatywności władz samorządowych i innych potencjalnych beneficjentów pomocy $\mathrm{w}$ regionach, co powoduje wzrost przedsiębiorczości rozumianej jako aktywność lokalna. Przedsiębiorczy, w myśl definicji, to taki, który potrafi dostrzegać potrzeby, doskonalić pomysły, wykorzystywać nadarzające się okazje, jest aktywny i dynamiczny. W warunkach integracji europejskiej, kiedy jednostki samorządu terytorialnego są często największym lokalnym inwestorem, czy nawet największym dysponentem kapitału (środki UE), można uznać region za podmiot przedsiębiorczości, a nie jedynie promotora przedsiębiorczości na swoim terytorium. Wyrazem takiego myślenia jest także nowa inicjatywa Komitetu Regionów, który na początku października 2009 r. rozpoczął realizację projektu - Europejski Region Przedsiębiorczości (EER - European Entrepreneurial Region). Jego celem jest rozwój prężnych i przedsiębiorczych regionów w całej Europie.

\section{Literatura}

1. Dziemianowicz W., Inwestycje zagraniczne jako czynnik rozwoju polskich regionów, Ekspertyza wykonana na zlecenie Departamentu Koordynacji Polityki Strukturalnej w MGPiPS, www.mrr.gov.pl.

2. Eurostat, 2008, Enterprises by size class - overview of SMEs in the EU, Statistics in fokus 31/2008.

3. Kotowicz-Jawor J., (red.) 2008, Adaptacja polskich przedsiębiorstw do rynku Unii Europejskiej, INE PAN, Warszawa.

4. Makieła Z., 2008, Przedsiębiorczość regionalna, Wydawnictwo Difin, Warszawa.

5. Miszczuk A., Żuk K., 2007, Samorzqd terytorialny jako stymulator lokalnego i regionalnego rozwoju gospodarczego [w:] Miszczuk A., Miszczuk M., Żuk K., Gospodarka samorzqdu terytorialnego, Wydawnictwo Naukowe PWN, Warszawa.

6. Ministerstwo Rozwoju Regionalnego, 2008a, Ocena postępów Polski w konwergencji z krajami UE oraz wpływ funduszy unijnych na gospodarkę w latach 2004-2007, Warszawa.

7. Ministerstwo Rozwoju Regionalnego, 2008b, Ocena wpływu funduszy strukturalnych na zwiększenie konkurencyjności przedsiębiorstw, Warszawa.

8. Ministerstwo Rozwoju Regionalnego, 2009a, Rozwój regionalny w Polsce. Raport 2009, Warszawa.

9. Ministerstwo Rozwoju Regionalnego, 2009b, Sprawozdanie roczne z wdrażania Programu Operacyjnego kapitat Ludzki 2007-2013 za 2008 rok, www.efs.gov.pl.

10. Osiński J., 2003, Administracja publiczna jako instytucjonalny warunek rozwoju społecznego [w:] Wzrost gospodarczy i rozwój społeczny jako paradygmaty wspótczesności, red. nauk. J. Osiński, Wydawnictwo SGH, Warszawa.

11. Potoczek A., 2001, Zarzadzanie w systemie samorzadu terytorialnego [w:] Adamiak J., Kosiedowski W. (red.), Potoczek A., Słowińska B., Zarzadzanie rozwojem regionalnym i lokalnym. Problemy teorii i praktyki, Wydawnictwo „Dom Organizatora”, Toruń.

12. Pracownia Badań i Doradztwa „Re-Source”, 2007, Analiza wplywu wsparcia udzielonego w ramach Działania 3.4 Zintegrowanego Programu Operacyjnego Rozwoju Regionalnego na wzrost konkurencyjności mikroprzedsiębiorstw, Raport końcowy zrealizowany przez Pracownię Badań i Doradztwa „Re-Source” na zlecenie Ministerstwa Rozwoju Regionalnego, Poznań, 12 listopada 2007.

13. Strojny J., 2006, Przedsiębiorczość w badaniach empirycznych Instytutu Geografii Wyższej Szkoty Informatyki i Zarzqdzania w Rzeszowie [w:] Rola przedsiębiorczości w podnoszeniu konkurencyjności społeczeństwa i gospodarki, red. Z. Zioło i T. Rachwał, „Przedsiębiorczość - Edukacja”, nr 2, Warszawa-Kraków. 
14. Swianiewicz P. z Herbst J., Lackowska M. i Mielczarek A., 2008, Szafarze darów europejskich. Kapitat społeczny a realizacja polityki regionalnej w polskich województwach, Wydawnictwo Naukowe Scholar, Warszawa.

15. Szomburg J., (red.) 2001, Polityka regionalna państwa pośród uwiktań instytucjonalno-regulacyjnych, IBNGR.

16. WYG International, PSDB, 2007, Instytucje otoczenia biznesu wspierane $w$ ramach Sektorowego Programu Operacyjnego Wzrost Konkurencyjności Przedsiębiorstw, lata 2004-2006: Określenie wplywu programu na ofertę usługowa oraz poziom jakości świadczonych ustug, Warszawa.

\section{Entrepreneurship in the Region versus the European Union funds}

The aim of the article is to answer the following questions:

- How the European Union funds help promote entrepreneurship in the region?

- What is the role of public administration in fostering entrepreneurship?

- Can the region be a subject of entrepreneurship?

The article approaches different aspects of entrepreneurship from a regional perspective particularly in the context of European integration and access to EU funds.

Supporting the creation and growth of businesses, in particular small and medium sized enterprises (SMEs); attracting investors and enhancing the productive capacity of regions are key ways by which public policy helps boost regional economies. This is also one of the priorities of EU regional policy and European funds. The main beneficiary of those funds in Poland are the local government units, which makes the role of public policies in fostering entrepreneurship even greater. As regions are competing for EU funds, the activity and creativity of local government units and other local actors is increasing, we can recognize a region itself as a subject of entrepreneurship. 